\title{
The Kaap Gold-Fields of the Transvaal
}

\section{Author(s): Fred. Jeppe}

Source: Proceedings of the Royal Geographical Society and Monthly Record of Geography, Vol. 10, No. 7 (Jul., 1888), pp. 438-446

Published by: Wiley on behalf of The Royal Geographical Society (with the Institute of British Geographers)

Stable URL: http://www.jstor.org/stable/1801453

Accessed: 25-06-2016 04:50 UTC

\footnotetext{
Your use of the JSTOR archive indicates your acceptance of the Terms \& Conditions of Use, available at http://about.jstor.org/terms
}

JSTOR is a not-for-profit service that helps scholars, researchers, and students discover, use, and build upon a wide range of content in a trusted digital archive. We use information technology and tools to increase productivity and facilitate new forms of scholarship. For more information about JSTOR, please contact support@jstor.org.

The Royal Geographical Society (with the Institute of British Geographers), Wiley are collaborating with JSTOR to digitize, preserve and extend access to Proceedings of the Royal Geographical Society and Monthly Record of Geography 
Under these circumstances, I thought it better not to pursue my explorations any farther, but to make a judicious retreat while the natives still doubted how to deal with us. When I turned my canoe round, however, and paddled back past the noisy villages, my retreat seemed to invite some of their inhabitants to give chase, and we underwent some moments of terrible excitement when the canoe would run aground, and hundreds-to our excited fancy it seemed thousandsof yelling savages would attempt to wade across the shallow water and seize us. Even little children armed themselves with matchets and knives, and standing ankle-deep in water shrieked out how they would like to eat us. Fortunately, although there were many guns among the men, they never attempted to fire at us, and it is therefore quite possible they only meant to scare us, either out of fun, or with an idea of driving us from the canoe and leaving our baggage to be plundered. However, we managed to keep out of their clutches, and there was no actual breach of the peace on either side, so that I am glad to think I have left no blood-feuds behind me. It was a great relief when we got back to the friendly and hospitable country of Arun, and thence to Old Calabar; we received nothing but kindness, and were generously supplied with food.

I have made a careful survey of the Cross river as far as I ascended it, and I am preparing a report of my journey. I have also made collections in natural history, which will be forwarded to Kew and the British Museum. The enclosed sketch-map will show the results of my expedition.*

\section{The Kaap Gold-fields of the Transvaat.}

By FRED. JEPPE, F.R.G.s.

Map, p. 484.

THE so-called Kaap gold-fields of the Transvaal or South African Republic, as shown by the accompanying portion of my new "Map of the Transvaal and Surrounding Territories," now in process of being compiled, are bounded in the west by the Kaap Plateau, called Godwaan Berg, in the south by a high range of mountains dividing the Kaap Valley from Moodie's gold-fields, in the east by a line drawn from Kamhlubana Peak to Nillmapin's Drift on the Crocodile river, and in the north by the last-mentioned river, from the said drift to a point opposite the Kaap Plateau.

* The boundary between the English and German protectorates has been inserted on the map as shown on the sketch sent by Mr. Johnston, but according to the agreement between the two countries the boundary is stated to follow the right river bank of the Rio del Rey from its mouth to its [unknown] source, thence in a direct line to the " Rapids" in the Cross river.-[Ed. 'Proc. R.G.S.'] 
The area of this territory, comprising about 800 square miles, is watered by the Kaap river, the principal source of which, named Queen's river, rises in the high mountain range in the south-east of Barberton, while the other two branches of the South and North Kaap river take their rise in the Kaap Plateau, combine into one river in the so-called Golden Valley, close to Eureka City, and join the Crocodile river in about long. $31^{\circ} 25^{\prime} \mathrm{E}$. and lat. $25^{\circ} 32^{\prime} \mathrm{S}$. The Crocodile river, named Ingevenja, Umgevenja, or Meguenha by the natives, which forms the northern boundary of the proclaimed gold-field, rises near Great Zuikerboschkop, south-west of Leydenburg, and joins the Komati close to the Lebombo range. It is here where the terminus of the Lourenço Marques Railway will be established on Transvaal territory.

The mountain range in the south, dividing the proclaimed gold-fields from Moodie's territory and Swasiland, forms the watershed between the waters running north towards the Kaap and Crocodile and south towards the Lomati or Komati rivers. The former is an affuent of the latter, and joins the Komati close to the Lebombo range. This mountain range rises in some peaks to an altitude of 7600 feet, and forms a huge branch of the Drakensberg, extending from the Natal border towards the Limpopo, north of Zoutpansberg. The altitude of the Godwaan Berg, which mountain presents a very precipitous face towards the valley to the east, is about 1500 feet above the valley, or 5800 feet above the sea ; and the altitude of Barberton, at the foot of Saddleback Hill, is considered about 3000 . Numerous small ranges and kopjes intersect the valley in all directions, and a long range of hills skirts the southern banks of the Crocodile river. Towards the north the Mauch Berg attains an altitude of 7200 feet, and the Spitzkop 5600. The highest altitude within the limits of our portion of the map reached by the projected railway is at Steckspruit, where the line ascends the Drakensberg range, 3283 feet; the highest altitude, 5884 feet, is reached at a farm named Bergendaal, a little beyond the left margin of our map. The Lebombo range, forming the boundary between the Portuguese possessions and the Transvaal, is merely a series of low ranges some eight or ten miles in width, and not higher than 900 or 1000 feet at the highest points.

The vegetation in the Kaap Valley is semi-tropical, but not very luxuriant, owing to the want of water. Most of the tributaries of the Kaap river, descending the valley from the surrounding high mountains, carry a great body of water during the rainy season, but they dry up and disappear almost entirely during the winter season. The valleys formed by the spruits or rivulets are lined with bush, very dense in some localities. The African mimosa thorn is the most prominent, but yellow-wood, iron-wood, and other African species are also found, besides a stray palm, cactus, and wild fig in the deeper valleys. The pasture is very rich during the summer months, but during the winter season the 
grass is burnt off by the prospector in search of reefs, or by the Boers of the neighbourhood, who formerly came into the valley with their flocks unconscious of the treasures hidden beneath the verdure. The pernicious habit of grass-burning, by which the growth of trees is crippled, if not destroyed, will make itself felt within a short time, as nothing is done by Government to preserve the wood indiscriminately cut down by the gold-mining companies for the consumption of the daily increasing number of steam-engines.

The numerous ruins of old Kaffir kraals scattered all over the valley show that the valley was formerly thickly inhabited by natives. Now there are no tribes to be found, and labour is supplied by the Swasi and Amatonga races living to the south of the fields. There is abundant evidence that the reefs were extensively worked by a white race in ancient times. Mr. Stuart, in his remarkable report on the Lisbon mine, ${ }^{*}$ refers to these old workings in the following terms :-

"The discovery of gold, as far as regards the English, may take date from 1870, but I soon found that the Transvaal must have been extensively worked by the miners of ancient times. I came upon the remains of old workings, showing that centuries ago mining was practised on a most extensive scale, that vast quantities of ore had been worked, and that by engineers of a very high order. I found quarries, tunnels, shafts, adits, the remains of well-made roads, and also pits of ore on the side of these old roads, apparently ready to be put into wagons. This ore was piled with as much regularity as if it had been placed for strict measurement, and it would seem as if these workings had been abandoned precipitately by the miners. I found in one instance that a gallery had been walled up with solid masonry. I could not conjecture the reason for this, but it may have been walled up by the miners themselves, under the impression that their abandonment of the works would be but temporary, and behind it there may possibly exist a continuation of the level. I was not able to remove the wall, as it was on a farm not at that time under your control. The native tribes, so far as I could ascertain by diligent inquiry, knew nothing as to who these ancient miners were, and have no traditions regarding them. I prefer to attribute these workings to the Portuguese, who are historically known to have had many trading possessions, and to have gained much gold in this section in the seventeenth century. My reasons for so attributing these workings is that they were acquainted with the use of gunpowder. But whether even a more ancient people, such as the Phoenicians, or whether the Portuguese did this work, is immaterial; the fact remains, and is open to all who will visit this country, that mining on a very extensive scale was carried on by some nation in the past."

The climate in the valley is considered unhealthy, particularly in the deep creeks running towards the Kaap river, but the gloomy ex-

* 'Report on the farm Lisbon,' by John M. Stuart. Published in April, 1883. 
pectations regarding Barberton have been completely falsified. $\mathbf{M r}$. Mathers, in his admirable work lately published,* says:-

"Many who journeyed to the town to settle, did so prepared to make sacrifices of health if it so could be that they would rapidly make money. Whether they have acquired more of this world's goods or not, it is certain they have gained in bodily health. The fact is that so far from the climate of Barberton being bad, it is exceptionally salubrious. There may be occasional cases of fever in the town, but they have found their beginnings beyond the boundaries of Barberton. These again may or may not be legitimately contracted cases. Men even with cast-iron constitutions could not long with impunity breathe malaria while sleeping in the open at low-lying fever-haunted spots; it is scarcely to be wondered at that men who shatter their frames with drink should sometimes succumb. There is no fever in the town proper, and little or no other sickness. It might have been expected that in the early days of growing Barberton the health of the town would be unsatisfactory, and yet we find that in the seven months ending with last November there were only 120 odd cases in the hospital; of these 107 had been discharged then, while others remained to become convalescent. Deaths in the town are few in number, and those from fever bear a small proportion to those resulting from other diseases or accident. Medical men have little or no work to do. They flocked to the place thinking to coin money out of fever patients; for a livelihood they either fitted, had to become scrip-sellers, or turn their hand to harder toil. There are hardly more than half a hundred graves in the Barberton cemetery, and the grave-digger, finding his occupation unprofitable, threw it up in disgust, and took to digging for gold."

Game has almost disappeared, frightened by the reports of the dynamite and the prospector's gun, and the Tsetse fly has gone away with the game, save in some parts of the valley. The valley, formerly teaming with all kinds of game, from the elephant to the steinbuck, is now deserted except by a stray leopard in the kloofs, or the lion on the Lebombo flats, where more game is found.

Regarding the geological formation of the Kaap Valley, professional men have not yet formed a decided opinion, or have been careful enough to express themselves in general terms only. Mr. Penningt says that the lowest strata observed in the Kaap Valley consist of a series of soft grey argillaceous shales or slates, so greatly tilted as to be found in some places almost in a vertical position. These beds were originally horizontal, being clay deposited by water; they have since been greatly metamorphosed by heat and pressure of many hundreds of feet of rock accumulated above them. Their being so much broken and tilted out of

* 'The Gold Fields Revisited,' by E. P. Mathers, F.R.G.s. Durban, 1887.

† 'A Guide to the Gold Fields of South Africa,' by W. H. Penning, F.G.s. Pretoria, 1883. 
position is due to plutonic or volcanic action, of which the granite and other eruptive igneous rocks, so plentiful in the valley, afford ample evidence. Now, Prof. J. A. Phillips, the great authority upon these matters, says, in his Elements of Metallurgy, p. 684:- "Native gold, in situ, is most frequently met with in quartz veins intersecting metamorphic rocks; and the metamorphic rocks enclosing gold veins are mostly chloritic, talcose, and argillaceous slates--auriferous veins also occur in granite. These slates, traversed by dykes of granite, are said to form the surface rocks in Swasiland and along the border of the Transvaal, which follows the southern boundary of the Kaap Valley. If this be so, the region offers a tempting field to prospectors, not only for alluvial gold, but also for lodes containing gold and other valuable metals.

"Above the slates is a series of hard shale sandstones and conglomerates, traversed by dykes of igneous origin. These beds are also tilted at various angles, and are broken or faulted in every direction; they are highly metamorphosed, especially near the trap dykes, where the sandstones are altered into quartzite. The beds of these series are exposed in the high krantz described, and extend beyond it over a good part of the Kaap Valley. The Krantz (Kaap Plateau) appears to have had its origin in a big $\mathbf{N}$ and $\mathbf{S}$ fault, with a downthrow to the east; its line being also more or less followed by an extensive dyke of greenstone. There are numerous quartz reefs in these rocks, for the most part vertical, or nearly so, and some of them have been proved auriferous.

"In certain portions of the Godwaan Plateau, and near its eastern edge, are some remnants of what must have been formerly a very extensive deposit of sandstone, probably of the age of the South African Coal Measures. These, when broken, are seen to be white crystalline sandstones, grits and conglomerates, which weather to a grey colour, and now, broken up into large lumps, form the boulders beneath which the gold nuggets were found. The sandstones also are traversed by veins of quartz, in some places highly ferruginous, and these, or some of these, have been proved to contain gold; but up to the present time (1883) very little work has been done upon the reefs in either of the formations described. The occurrence of these groups of rocks, which are known to enclose auriferous veins elsewhere, and the prevalence of quartz veins and trap-dykes running in various directions, render the geology of this district important to the question under consideration. The first sories of rocks described are doubtless of lower or older Palæozoic age; the second probably belong to the rewest rocks of that period, or the oldest of the Upper Palæozoic; the third are, in the writer's opinion, certainly of that age, Upper Palrozoic, and belong to the Carboniferous series."

Regarding the Barberton formation Dr. Schenck, a German geologist, who lately visited the Kaap and all the other gold-fields, says that the Barberton formation consists of very old, and in most instances high 
metamorphosed rocks, composed of slate and sandstone, with interposed eruptive rocks of greenstones (diorite, serpentine, \&c.). These rocks are highly tilted, dipping invariably at great angles, often perpendicular, and run from east to west. In this formation the gold-bearing veins or reefs are situated, and these with few exceptions run in the same direction (this is, for instance, the case with the reefs at Moodie's and with the Shebacte), nearly always accompanying the eruptive rocks. The gold, in the doctor's opinion, came from the interior of the earth with the eruptive rocks to the surface, and was thereafter concentrated in these reefs, which consist of quartz, and often contain iron along with the gold. This formation probably corresponds in age with the Silurian formation of Europe, and is found also in Swasiland, Zoutpansberg, and the recently discovered gold-fields of the Tugela. There is no young formation overlying these rocks at Barberton, but in the Drakensberg and the Witwatersrand, a younger formation lies unconformably over the older rocks. This is of Devonian age. The Barberton formation, he is inclined to think, proceeds beneath this formation in a westerly direction to Witwatersrand, and thence to Bechuanaland.

A German writer, describing the gold-fields, ${ }^{*}$ says that the formation embedded in the reefs consists chiefly of slate running horizontal with the reef, and being very hardened, causes great trouble to the miners, who call it blue bar. He says further, while all reefs as a rule run from west to east, auriferous veins found in reefs running from north to south form a peculiarity of the Sheba Mountain, which appears to be the knotpoint of various rich quartz veins. The richest of these are the socalled Golden Quarry, showing rich veins on the surface, and requiring no shaft sinking, the reef being worked from the surface (Tagbau).

A brief outline of the discovery of the Kaap gold-fields will be sufficient for the purposes of this paper.

Mauch, on his trip from Delagoa Bay to Lydenburg in 1870, found traces of gold in the Drakensberg ranges traversed by him, but an attack of fever contracted at Delagoa Bay prevented closer investigation.

About the same time, in August 1870, J. Britton discovered auriferous reefs near Marabastad, and proceeding from there to Lydenburg, found alluvial gold in the neighbourbood of Spitzkop, for which in March 1871 he, together with Thomas M'Laughlan and Jas. Sutherland, claimed the reward promised by law of 31st January, 1871, to the first discoverer of gold. The first company, the Lydenburg Gold Prospecting Compauy, was established in March 1871 for the purpose of prospecting in the district of Zoutpansberg and Lydenburg. In 1872 Mr. C. F. Osborne, in an exploring expedition, discovered auriferous reefs in the Komati River valley between the present territory of Moodie's Gold Mining and

* 'Die Kaap Gold Fields in Transvaal,' by P. Emmerich, in Sheba Range. Published in Petermann's ' Mitiheilungen,' 1887. Heft 5. 
Exploration Company and the present Komati gold-fields, but he did not proceed further north towards Barberton.

In the meantime digging operations were carried on at Eersteling, near Marabastad, and in the district of Lydenburg, but it was not before the 14th May, 1873, that the gold-fields in the ward Ohrigstad river were proclaimed and set open as a payable gold-field. Spitzkop, Mac Mac, on the farm Geelhoutboom, and Pilgrim's Rest, on the farm Poniiskrantz, became the chief centres of the New Caledonia gold-fields. Two banks were established, hotels, canteens, and stores were built, and the digging population increased to about 900 men, scattered over a distance of six miles along the creek. There was not much reef-mining; alluvial was principally prospected for and worked, but this was found from the bed of the creek to the very top of the high ridge facing the creek. The largest nuggets, weighing 119, 123, and 215 ounces, were found in 1875, the 123-ounce nugget 30 feet below the surface at the head of the creek. The total quantity of gold found and exported from these fields cannot be ascertained. The official returns of gold export through Natal and the Cape ports only represent a small portion of the gold obtained exported by the banks.

But the mere fact of gold being found in large nuggets proved to the experienced digger that the ground was "patchy," and that no regular "lead" existed. The digging population gradually fell off and dwindled down to a small community; then the Secocoeni war deprived the diggers of labour, and they had to exchange the gun for the spade. A few diggers held on, and met with a fair measure of success; many left the country in disgust, but some with handsome fortunes, the proceeds of years of hard toil, or the proceeds awarded them by the companies which appropriated their claims.

During British rule, from 1877 to 1881, there is no record of any progress made in gold-mining, but as soon as the country was given back to the Boers gold-mining entered a new era, what may be termed the concession era. The proclamation of the Ohrigstad river ward was withdrawn, and concessions granted to the owners of the soil, giving them the free and undisturbed right to all minerals formerly claimed by the State. Many of these concessions lapsed by reason of non-payment of the subsidy; others had to be bought back at high prices when the Government wished to proclaim the ground as a public gold-field.

The progress the Kaap gold-fields have made up to the time the reefs were discovered at Witwatersrand is most remarkable. The list of goldmining companies now established at the Kaap gold-fields, published by the Barberton Chamber of Mines, shows the number of eighty companies. established in the proclaimed Kaap gold-fields, including sixteen on Moodie's ground, with a total capital of 3,570,500l., of which upwards of one-third is paid up.

Regarding the township of Barberton Mr. Mathers says:- " Three 
years ago Barberton had no existence. It was as destitute of evidences of civilisation as when the now migrated lion and zebra, elephant and tiger, roamed undisturbed in the mountain solitudes now peopled by its energetic inhabitants. At that time prospecting parties left Moodie's to explore the locality. A member of one of these, Mr. Graham Barber, a relative of that esteemed Natal colonist, Colonel Bowker, discovered in a deep gorge the reef which gives the town its name. Barber's reef pinched out, and Mr. Rimer's battery, which was erected to crush the stone of the adjoining Umvoti reef, is now grinding out gold near the Sheba Company's property. A few more finds were made, and some tents went up on the spot. As time wore on these gave place to Kaffir huts and grass and reed houses, and the population, which gathered slowly at first, received large additions when the exciting news of the discovery of the famed Sheba spread throughout South Africa. In July of last year the town was composed of thirty houses of wood and iron, and as many mud and thatch dwellings, together with the primitive structures I have just named. To-day Barberton is a town of about 4000 inhabitants, and is a financial and trading centre for a population of another 4000 .

"The town proper has a circumference of about a mile, but beyond this there are many dwelling-houses and other buildings dotted at irregular intervals over a large area. Rising ridges branch out from each end of the town, and along these spurs some very commodious and even elegant residences have been erected. One of the several good buildings which catch the eye is an imposing two-storied red-brick pile in the market square, put up by Messrs. Lewis and Marks. Among the other buildings of importance may be ranked the two exchanges, the new club-as comfortable as any in South Africa-substantial places of public worship, some good hotels, a theatre, two music-halls, and canteens innumerable, four banks, a hospital, Government offices, \&c."

The gold-fields are approached by three routes, viz. viâ Delagoa Bay, Natal, and viâ Capetown or Port Elizabeth, Kimberley and Pretoria, the first-mentioned being the shortest, owing to the close proximity of Delagoa Bay. On the authority of an old digger, J. W. Barrington, this route is only safe from 1st June to the last of August. The reports regarding the unhealthiness of Delagoa Bay and the surrounding country are, however, much exaggerated. Sir Thomas Tancred, the contractor for the railway from Lourenço Marques to the Komati, declared that of his large gangs employed on the line throughout the whole of the contract time, June to December, the white lives lost on the line did not exceed seven, and those deaths were not all from fever; drink and accident being more often the cause. As for himself, he declared he had enjoyed good health and had always been occupied; where a gang of all sorts and conditions of men had to be kept together and advantageously worked in a place like the evil-reputed flats of Lourenço 
Marques, it required special attention to keep them at it, overcome fears, and avoid panic." *

The distance from Lourenço Marques to Barberton, which has to be travelled on foot, with native runners carrying luggage, is about 150 miles, which distance is now shortened by 42 miles to Movini station, the present goods terminus of the Lourenço Marques Railway, accessible to traffic, while the station on the bank of the Komati, to which the railway was opened, is 10 miles further on, but not accessible to wagons.

The second route through Natal is 472 miles, of which 187 miles are travelled by rail to Ladysmith, and the rest by post-cart or coach in five days. This route goes by way of Newcastle, Ermelo, and Lake Chrissie. There are some other routes used by transport-riders through Gregtown, Zululand, and New Scotland, said to be much shorter.

The distance from Cape Town viâ. Kimberley and Pretoria is about 1200 miles, of which 647 are travelled by rail to Kimberley, and the rest in comfortable American coaches in five days.

The railway from Lourenço Marques to the Lebombo was opened officially on the 14th December, 1887, but only as far as the Komati, a distance of 52 miles. The line is to be carried 9 kil. or 5 miles further through the Komati Poost to this side of the Lombobo, where the terminus is to be on Transvaal territory. As the boundaly line runs along the highest ridge of the Lebomko, where no station can be estab. lished, the terminus must necessarily be made on Transvaal soil. From here the line is to be made by the Netherland South African Company, which obtained the concessions granted to some parties in Holland in May 1885. The distance from the boundary to Pretoria, as surveyed by Col. Machado, R.E., is 470 kil. or 292 miles, making the total distance from Lourenço Marques to Pretoria 561 kil. or about 350 miles. The first section to Nilspruit, 120 kil. or $74 \frac{1}{2}$ miles, is soon to be commenced, unless the direction of the line is altered, and brought nearer to Barberton through the Kaap Valley.

In the meantime Natal is pushing on the extension of the line from Ladysmith towards Newcastle, and the Cape Government are desirous of carrying a line from their border through the Orange Free State to the Vaal river.

* Report of the Special Correspondent to the Natal Advcrtiser at the opening of the Delagoa Bay Railway, N.A., 19th December, 1887. 


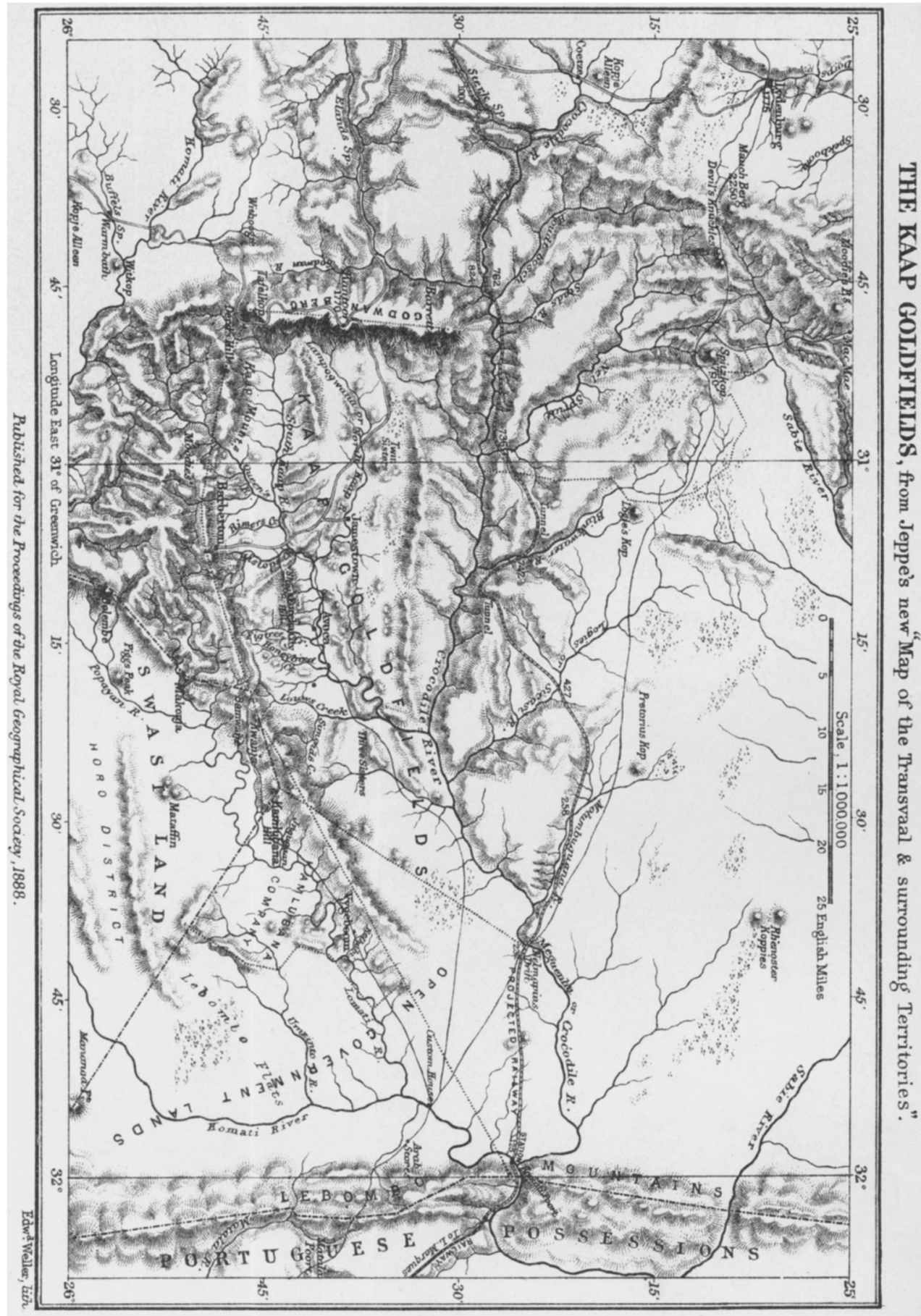

